\title{
Information System Development Using Microsoft Visual Studio to Speed Up Approved Sample Distribution Process
}

\author{
Carolline Audrel Vellicia Wijaya ${ }^{1}$, Hery Hamdi Azwir ${ }^{2}$ \\ ${ }^{1,2)}$ Faculty of Technology, Industrial Engineering Department, President University \\ Jl. Ki Hajar Dewantara \\ Kota Jababeka,Cikarang, Bekasi - Indonesia 17550 \\ Email: putrisally99@gmail.com, hery.azwir@president.ac.id
}

\begin{abstract}
An approved sample is a sample that has been tested in a laboratory and approved by experts who understand it to be a sample in the production process. In the current process, all sample identities are written manually and repeatedly inputted by several people. This manual process is a major bottleneck in producing approved samples so that it can cause delays in the production process. This manual process causes employees to have to work overtime 2-3 hours every day to complete the approved sample which must be issued on the same day. To overcome this problem, an information system was developed to eliminate bottlenecks in this process. Design and development of software use the SDLC method which includes information gathering to find out business processes, DFD analysis, design user interface, ERD and database, and continued with development using Visual Studio, Microsoft Access, Microsoft Excel, and VBA as well as Microsoft Outlook as supporting programs. After the software is implemented it can be seen that the bottlenecks that have occurred so far can be removed and the work completed faster, no additional overtime is required and can even be one day sooner. Besides all the data is stored more neatly and facilitates the process of finding data.
\end{abstract}

Keywords: SDLC, Approved Sample, DFD, ERD, Database, Visual Studio.

\section{ABSTRAK}

Sampel yang disetujui adalah sampel yang telah diuji di laboratorium dan disetujui oleh pakar yang memahaminya untuk menjadi sampel pada proses produksi. Dalam proses saat ini, semua identitas sampel ditulis secara manual dan diinput berulang kali oleh beberapa orang. Proses manual ini menjadi hambatan utama dalam membuat sampel yang disetujui sehingga dapat menimbulkan keterlambatan proses produksi. Proses manual ini menyebabkan karyawan harus bekerja lembur 2-3 jam setiap hari untuk menyelesaikan sampel yang disetujui yang harus dikeluarkan hari itu juga. Untuk mengatasi masalah tersebut, dilakukan pengembangan sistem informasi yang dapat menghilangkan adanya hambatan dalam proses ini. Desain dan pengembangan piranti lunak menggunakan metode SDLC yang meliputi pengumpulan informasi untuk mengetahui proses bisnis, analisis DFD, desain ERD dan basis data dan dilanjutkan dengan pengembangan menggunakan Visual Studio, Microsoft Access, Microsoft Excel, dan VBA juga Microsoft Outlook sebagai program pendukung. Setelah piranti lunak diimplementasikan dapat dilihat bahwa hambatan yang terjadi selama ini dapat dihilangkan dan pekerjaan lebih cepat diselesaikan dan tidak dibutuhkan tambahan waktu lembur bahkan dapat satu hari lebih cepat. Selain itu semua data menjadi tersimpan lebih rapih dan memudahkan proses pencarian data.

Kata kunci: SDLC, Approved Sample, DFD, ERD, Database, Visual Studio.

\section{Introduction}

Information is the result of data processing so that it becomes an important form for the recipient and has a usefulness as a basis for making decisions that can be felt directly or indirectly in the future (Kadir, 2002). To make it easier to obtain information, information technology can be used. Information technology itself is electronic equipment, especially computers, which are used to process data into information (Kadir, 2002). Information systems are interactions between information technology, users of information technology, and data sources which will produce information that is useful in providing information and making decisions (Azwir \& Patriani, 2017). Information systems that use computers are commonly called computer-based information systems (Computer-Based Information Systems or CBIS). 
Recently, a good quality product is an essential need for people in the world to have a good life. Many manufacturing organizations try to make any kind of things or products for people around the world to make an easy and comfy life for everyone. To make a high-quality product, the company always need to test all the product that will be produced. But it is impossible to test all the products that will be distributed to the customer. That's why the company make a sample for each of the product. The producer of the product in the area need to know which product is good or not by comparing it with the sample that has been approved by special people in the company as a good product.

At PT. XX, there is a department that has a responsibility in accepting the sample that has been tested by the laboratory to become an approved sample. In each day, there are more than 100 samples from several departments that must be released in the purposed of the production team running as the schedule. In the last step before the sample be released is in the department that has a responsibility to accept the sample and distributed it only consist of 1 person. The record of the approved sample must be input manually to excel and database several times. Each department one time. It took time. The fastest time for one approved sample to be made is one day based on the observation. Because must be input manually by several departments, one time there will be more than one samples in each of concerned department that cannot be released as the schedule. Because of the manual system, sometimes the production cannot be running as the schedule because the approved sample is not finished. The observation is made after the sample is made by the designer in the engineering department because the main focus in supporting the user is after the sample be made until the sample is distributed. With limited time and resources, there were several cases when the approved sample did not finish based on the schedule and it makes the production cannot be run. These situations become the bottleneck in this process. Seeing this situation, the information system can be very useful to help this problem. Making a new system that makes the cycle of approved sample production has become more efficient will become a great help for PT. XX in producing the product. The process in the methodology for creating and develop the systems in systems engineering is the meaning of the System Development Life Cycle (SDLC) (Kute \& Thorat, 2014). Using this method, the system can be made after analyzing the problem. This method will be implemented in this study. Using Visual Studio 2019 as the main tool in making the system need by the user that will make approved sample production become more efficient and did not takes time.

\section{Methods}

Based on the reference (Rosenblatt, 2013) there is intense competition in the global area from the aspect of information technology. Information technology in this era can influence the success or failure of the business. (Putra, Fifilia, Christian \& Sudarma, 2015) To develop information technology, an information system is made with the function to combine it with people, and data to provide support for business. To develop an information system, some steps needed to be passed. This step called System Analysis and Design. The people that analyze and design the information system called systems analysts. Based on the reference (Kendall and Kendall, 2014), a comprehensive range of qualities are needed by an analyst to make a successful system. With this ability, an analyst can analyze and design a great information system for business and another area.

\subsection{System Development Life Cycle (SDLC)}

(Sharma, 2017) System Development Life Cycle (SDLC) is the cycle of analyst and user activities that can be used to develop the systems. The systems can be designed with one of the methodologies that are System Development Life Cycle (SDLC) by providing 7 phases of development (Kendall and Kendall, 2014). The 7 development are:

- Identifying problems, opportunities, and objectives

- Determining human information requirements

- Analyzing system needs

- Designing the recommended system

- Developing and documenting software

- Testing and maintaining the system

- Implementing and evaluating the system 


\subsection{Data Flow Diagram (DFD)}

According to (Le Vie, 2000), the relationship between various elements in the program or system is what the Data Flow Diagram (DFD) visualized. DFD is a useful strategy in the representation of a framework in abnormal state detail by demonstrating the way input information handled to output results through successions of the process. DFD utilized by framework creator and others when starting examination stages to envision the present system framework or another that might be fundamental to meet the new need. (Percy \& Amos, 2016) System analyst selects working with DFD, mostly when they need a rich comprehension of the limit among present system frameworks and proposed system frameworks. 4 major components in DFD are entities, process, data stores, and flow of data.

\subsection{Entity Relationship Diagram (ERD)}

(Rosenblatt, 2013) When there are several entities, there will be a relationship between these entities. This is one of the basic knowledge in the design of the system. This becomes the first thing to do after define and analyze the business process. To design ERD, the first thing to do is to list the entities that be identified based on the business process and user requirements. The simple thing to do is think about the relationship between each of the entities. It will be easier if the business process that is made is right and have through the right steps based on the tool that be used, like the System Development Life Cycle (SDLC).

\subsection{Data Dictionary}

(Kendall \& Kendall, 2014) In the design flow diagram of data, each of the data must be explained carefully to make it more understandable for the user and future admin or system analyst or can be said as references work. Understand the development of a data dictionary makes system analysts understand the concept and the way the system works. There is 4 kind of data dictionary which are Data Dictionary of the Structures, Data Flow Dictionary, Data Storage Dictionary, and Data storages of Elements. Not all the kind of data dictionary must be defined and develop. The main data dictionary that must be made are Data Storages and Data Flow. In this research, the data dictionary that will be made are Data Dictionary of the Processes, Data Flow Dictionary, Data Storage Dictionary.

\subsection{Process Specification}

(Kendall \& Kendall, 2014) Process Specification or mini specs are the processes in a data flow diagram of another process that will make it become a child diagram. The common logic and design of object-oriented can be generated with the process specification. This will convert the data from the input process to the output process. 3 main objectives in making process specification are: make the analyst understand the way of the process work, then it will reduce equivocalness of the process; To make the analyst gain all the detailed specifications about the accomplished process, and last main objectives are to make sure the design of the system.

\subsection{Visual Studio}

Visual Studio is a development application from Microsoft. This application-driven programming language in making and develop computer programs. Or in general Microsoft Visual Studio is a complete software (suite) that can be used to develop applications, for example, business applications, personal applications, or application components, in the form of console applications, Windows applications, or Web applications. (DGilca \& Marian, 2019) This application includes a code editor that works like a debugger. Visual studio is supported by 36 different programming languages. With this application, user can make the program, code editor, debugger, design, etc.

\subsection{Microsoft Access}

Microsoft Access is one of development program from Microsoft. This application is to be used to make database management. This database management system can be linked will another development program by Microsoft. This application stores data in its format based on the Access Jet Database Engine. This database is supported by VBA and another programming language. Another meaning of Microsoft Access is an application that is useful for creating, processing, and 
managing databases, or better known as databases. (Roger \& Dave, 2015) A database is a collection of tabular data archives that are interrelated to produce information. Data is used as input to be processed into information. The main function/function of Ms. Access is to handle the process of data manipulation and the creation of a system. The presence of Microsoft Access can be used as a medium for creating basic web applications.

\section{Result and Discussion}

The first stage in software development is doing information gathering to find out the basic business process of the system to be developed. Figure 1 shows the proposed business process as a result of the analysis of the current process.

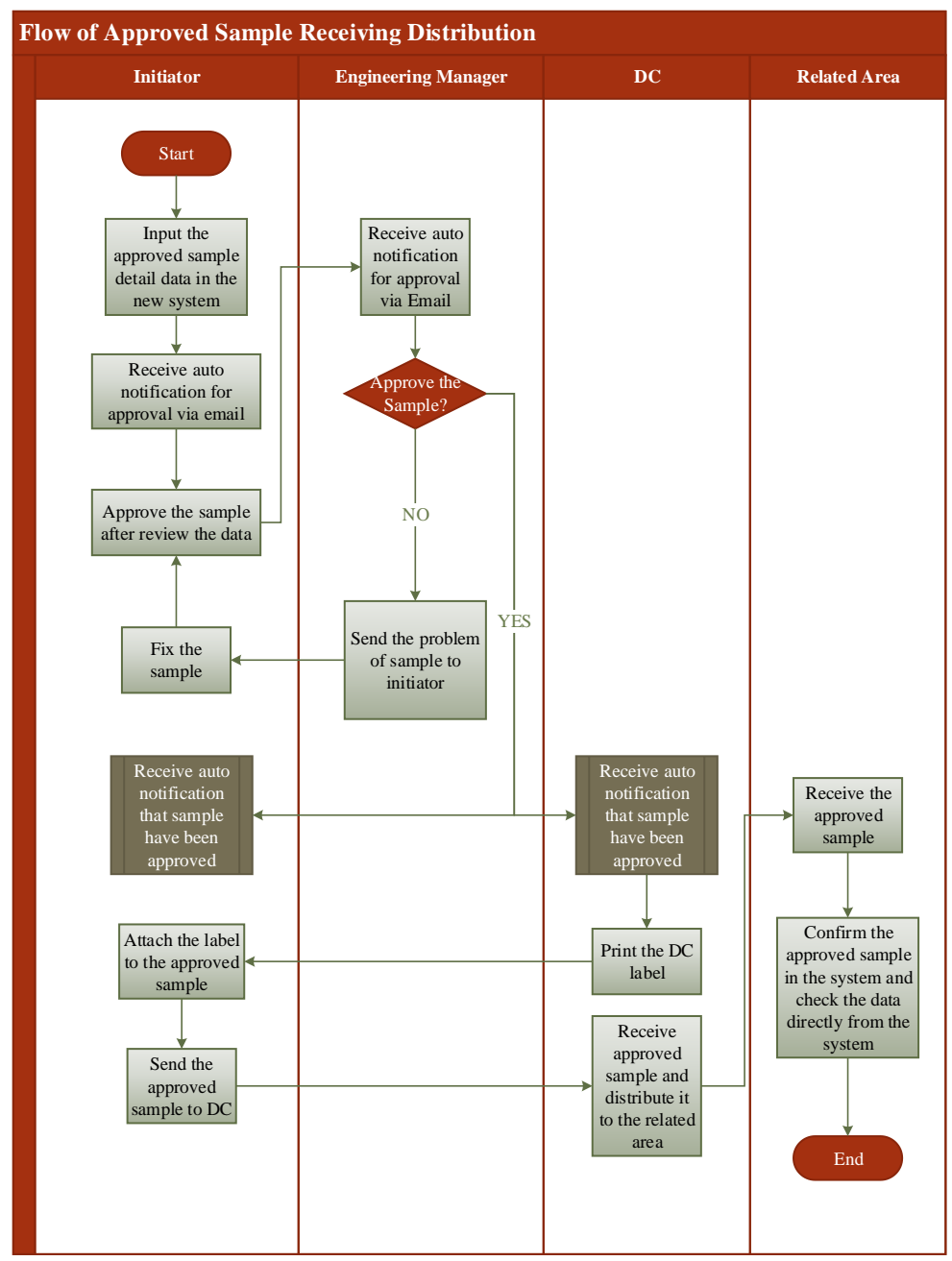

Figure 1. Proposed Flow of Approved Sample Distribution

After the proposed business process is found, the next step is analyzing the current system by using a data flow diagram (DFD) and followed by a data dictionary description and process specification. The DFD description is started by a context flow diagram that explains the relationship between the system and it's all entities. Figure 2 shows the situation. After defining the context level diagram then continue with elaborating in more detail by describing DFD 0 which explains in more detail about the relation of entire entities to subsystems inside including data store. The relationship also shows the data flow. Figure 3 shows this DFD 0. Figure 4 explains about exploding of a process of DFD 0. 
JIE, Vol. 5, No.1, April 2020: 14-24
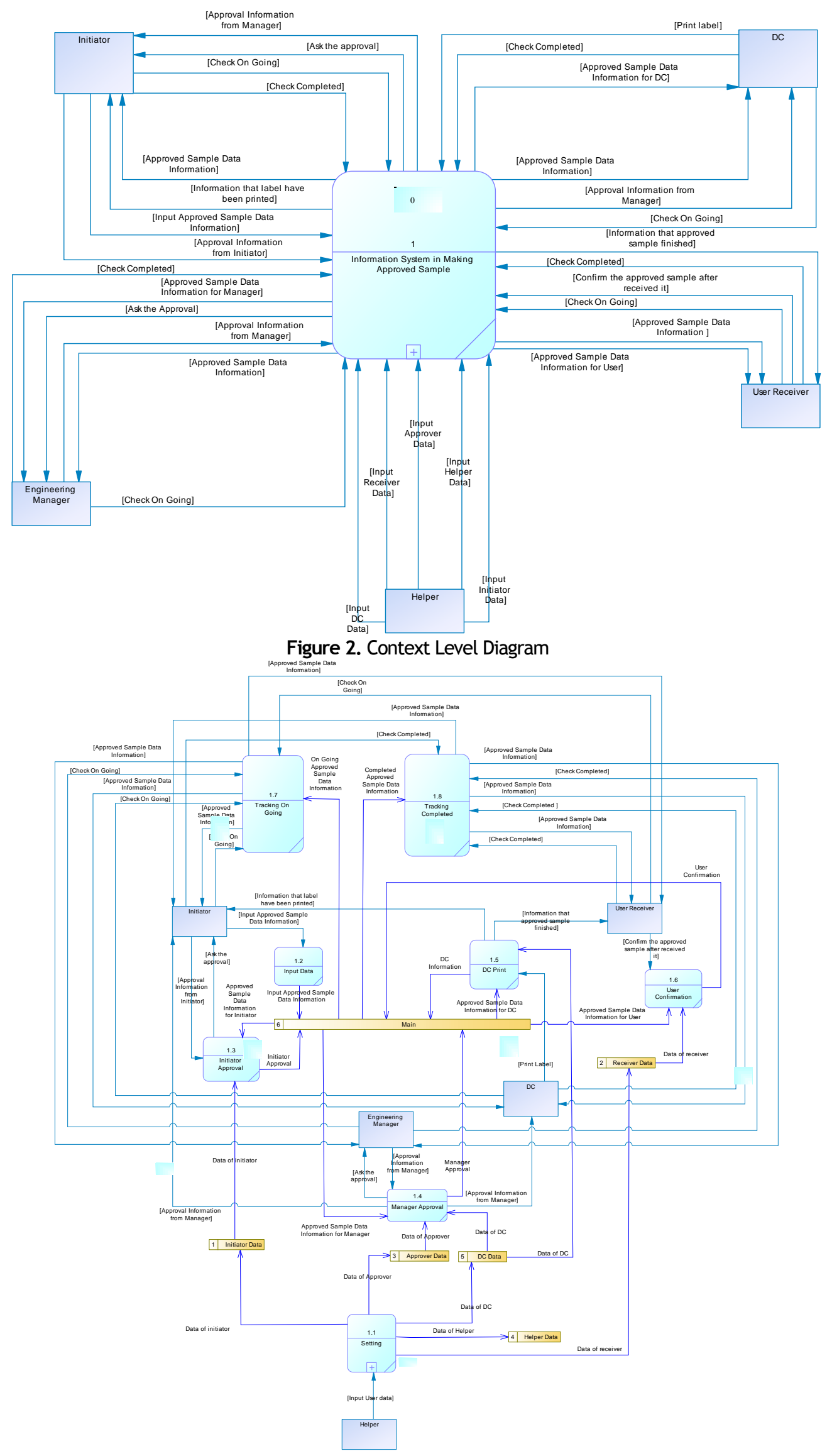

Figure 3. Data Flow Diagram (DFD) Level 0 


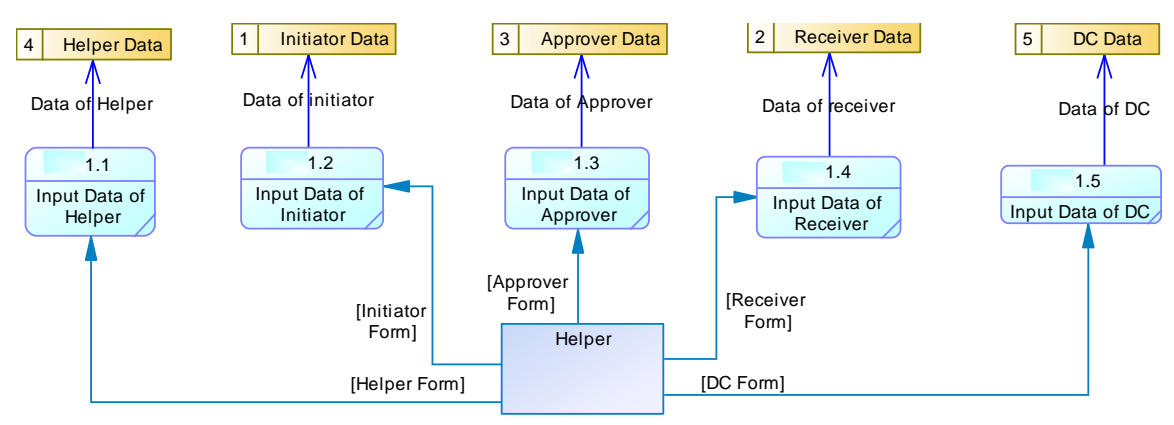

Figure 4. Data Flow Diagram (DFD) Level 1

After completing the DFD analysis including data description and process specification then continue with designing the user interface. Figure 5 and figure 6 shows a user interface design to provide clear communication between the user and the system. Figure 5 shows the main menu of system interface and Figure 6 shows the E-form that be made as to the main program of this new system

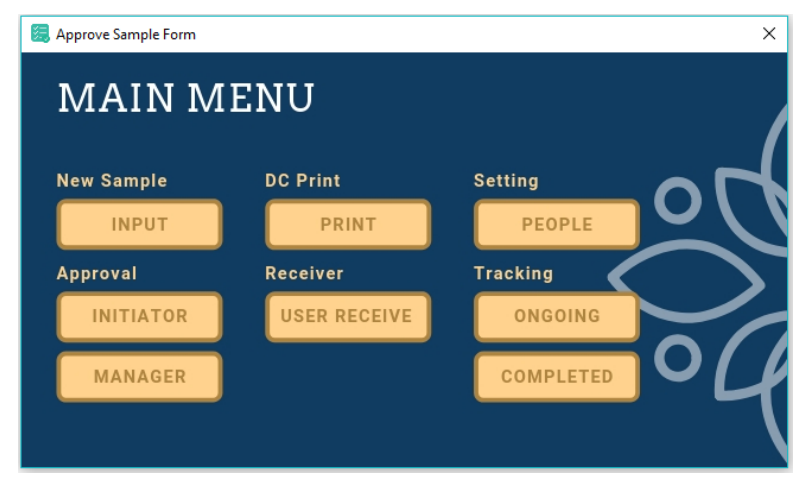

Figure 5. Main Menu of New System

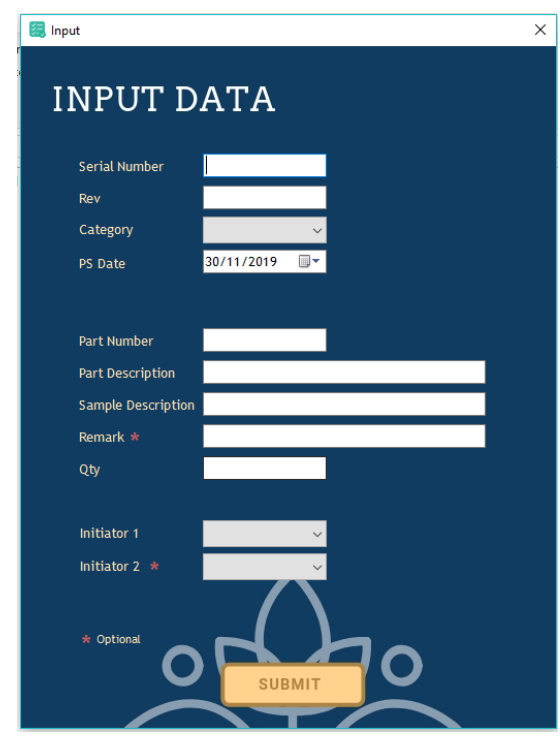

Figure 6. Input Menu (E-Form) of Approved Sample Data

Besides user interface design, another task to be prepared is designing a database by creating ERD and then continue with designing table relationships that follow ERD descriptions. Figure 7 shows the ERD created. Figure 8 shows some contents of the database. This ERD is made to design the database of the system. The 
main database of this system is storing all of the data that inputted by the initiator and the information of the date time and user who approved the sample, print the label and received the approved sample.

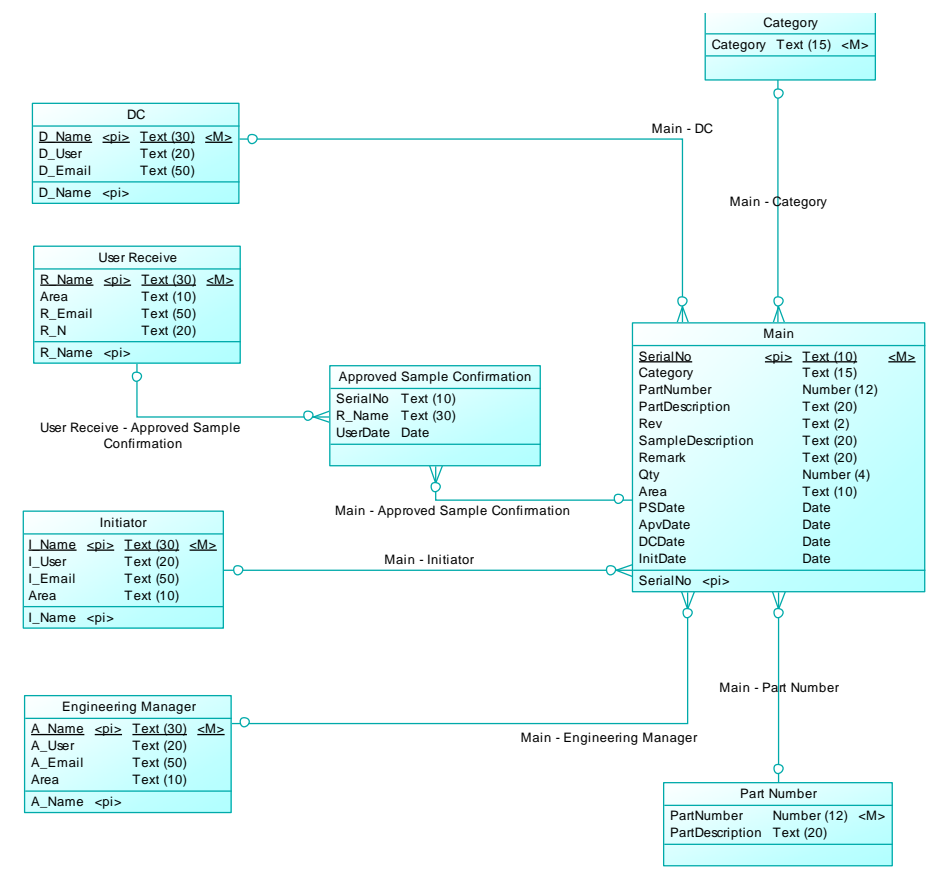

Figure 7. Entity Relationship Diagram (ERD) of the Approved Sample Distribution Information System Database

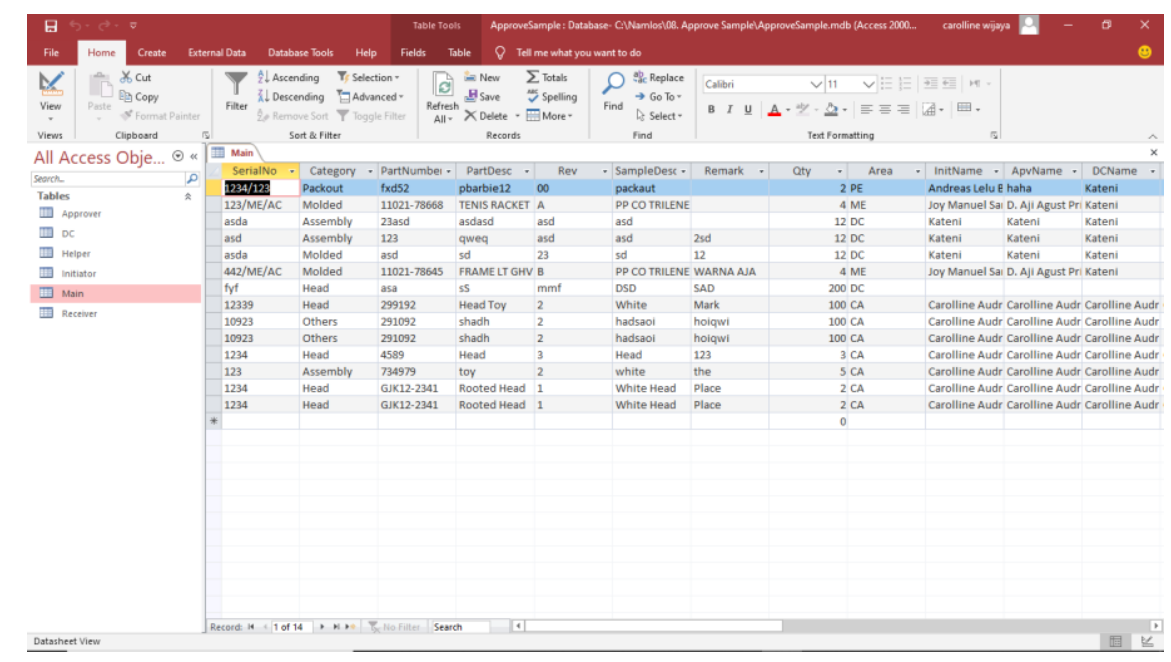

Figure 8. Main Database Design

The development of the analysis and design of the information system is handled by Visual Studio 2019. By combining Microsoft Access and VBA then the system is developed and tested by the following test scenario that is shown in Table 1. The testing is conducted to ensure the system can run smoothly. Table 1 shows the testing result of the Input Data.

Table 1. Input Testing Result

\begin{tabular}{|c|l|c|c|}
\hline Steps & \multicolumn{1}{|c|}{ Action } & Result & Status \\
\hline 1 & Click Approved Sample Application & The main menu appeared & OK \\
\hline 2 & Click the INPUT button & Approved sample form appears & OK \\
\hline \multirow{2}{*}{3} & Fill Serial Number of samples & $\begin{array}{c}\text { Except Remark and Initiator 2, all the } \\
\text { fields must be filled. If there are }\end{array}$ & OK \\
\cline { 2 - 4 } & Fill Revision of the sample & \multicolumn{2}{|c|}{ OKeld } \\
\cline { 1 - 4 }
\end{tabular}




\begin{tabular}{|c|c|c|c|}
\hline Steps & Action & Result & Status \\
\hline & Choose Category of the sample & \multirow{9}{*}{$\begin{array}{l}\text { fields that not be filled, "Please fill } \\
\text { blank fields" Ok. } \\
\text { If all the required fields have been } \\
\text { filled, "Confirm submit?" Yes or No. }\end{array}$} & \\
\hline & Choose the PS Date of the sample to be made & & \\
\hline & Fill the Part Number of parent toy of the sample & & \\
\hline & $\begin{array}{l}\text { Fill the Part Description of the parent toy of the } \\
\text { sample }\end{array}$ & & \\
\hline & Fill the Sample Description of the sample & & \\
\hline & Fill the remark if needed & & \\
\hline & Fill the Quantity & & \\
\hline & Choose the Initiator 1 and Initiator 2 if needed & & \\
\hline & Click Submit & & \\
\hline 4 & Click Yes or No & $\begin{array}{l}\text { If Yes, then Outlook Email will be } \\
\text { automatically opened. If No, back to } \\
\text { the form }\end{array}$ & $\mathrm{OK}$ \\
\hline 5 & Click X button & The menu will be closed & OK \\
\hline 6 & Click Send in the email & Success & OK \\
\hline
\end{tabular}

Finally, after the system has been tested and implemented, the last part is the evaluation of new system performance comparing to the previous one. The comparison is made by comparing the current process business process and the proposed business process which can be seen in Figure 8-9 and Table 2.

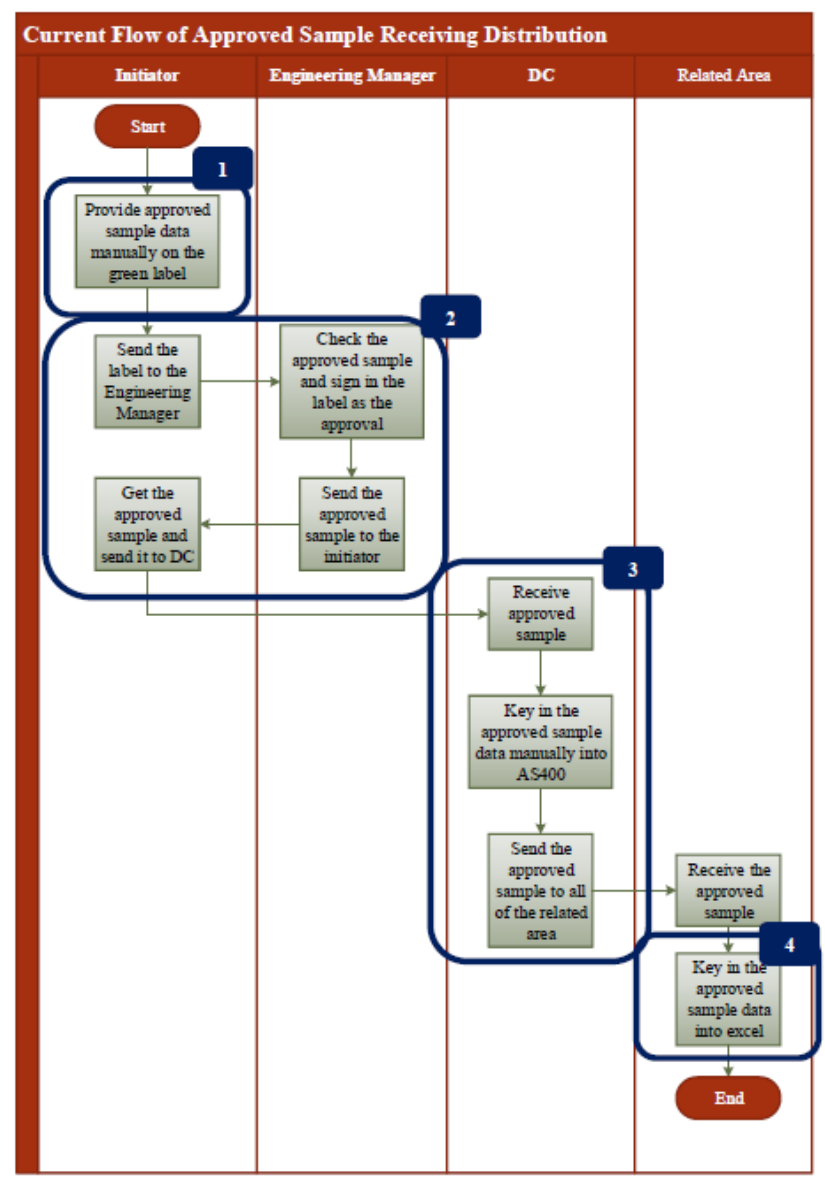

Figure 8. Current Business Process of Approved Sample Receiving Distribution 


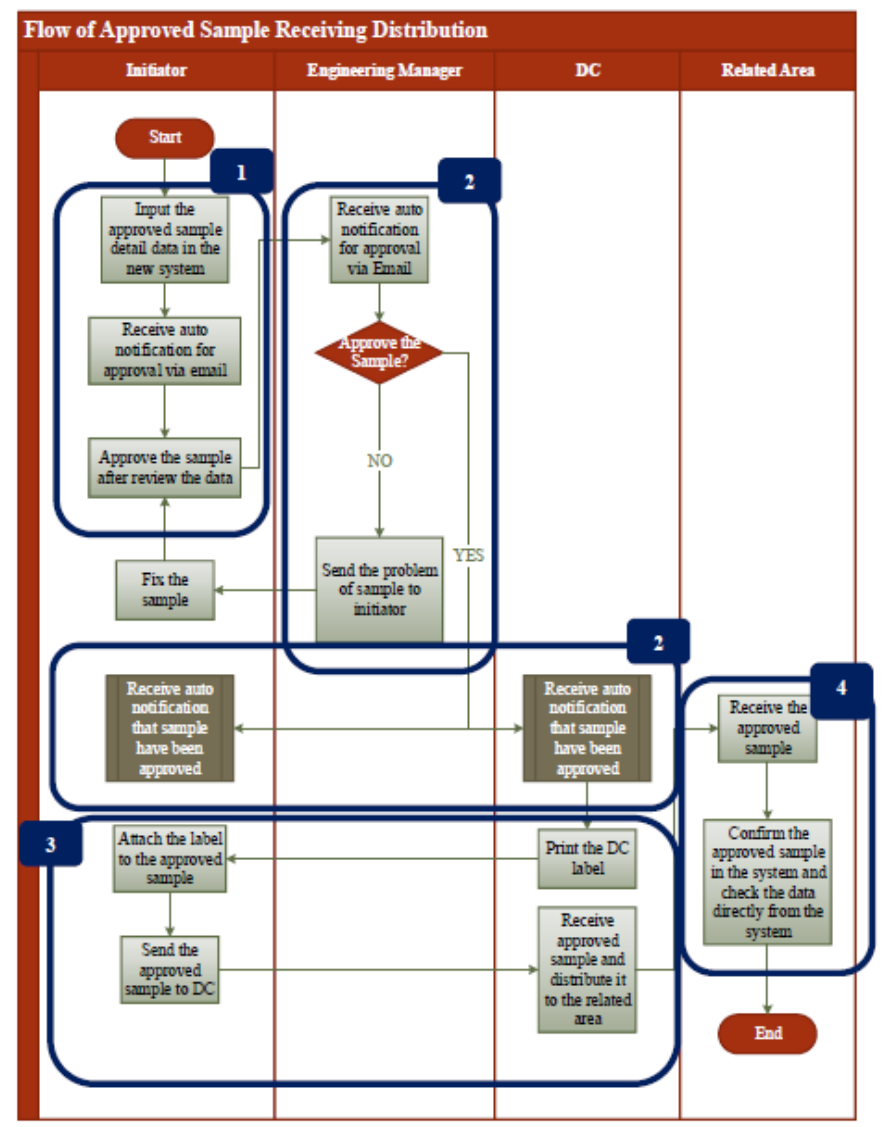

Figure 9. Proposed Business Process of Approved Sample Receiving Distribution

Table 2. Comparison Between Current Business Process and Proposed Business Process

\begin{tabular}{|c|c|c|}
\hline \multirow{2}{*}{ Number } & \multicolumn{2}{|c|}{ Flow Business Process Comparison } \\
\hline & Current & Proposed \\
\hline \multirow{2}{*}{1} & $\begin{array}{l}\text { The initiator made approved sample data } \\
\text { by manually write it in the green label }\end{array}$ & $\begin{array}{l}\text { The initiator made the approved sample data by } \\
\text { directly fill the e-form in the new system }\end{array}$ \\
\hline & & $\begin{array}{l}\text { Initiator check and review the data of the } \\
\text { sample by approved the sample in the system }\end{array}$ \\
\hline \multirow{4}{*}{2} & $\begin{array}{c}\text { Initiator directly send the approved } \\
\text { sample with the data of the sample } \\
\text { written in the green label to the } \\
\text { engineering manager to be checked and } \\
\text { approved }\end{array}$ & $\begin{array}{l}\text { Initiator ask the approval to the manager by } \\
\text { sending the email automatically after approved } \\
\text { the sample }\end{array}$ \\
\hline & $\begin{array}{l}\text { Manager review the data of the sample } \\
\text { when the initiator sends it directly to the } \\
\text { manager and if there is a problem, the } \\
\text { initiator must change the label and make } \\
\text { a new label with new data }\end{array}$ & $\begin{array}{l}\text { The manager reviews the data of the sample } \\
\text { from the email sent by the initiator or from the } \\
\text { system. If there is a problem, the manager will } \\
\text { give the feedback via email, and the initiator } \\
\text { can edit the sample in the system }\end{array}$ \\
\hline & $\begin{array}{l}\text { The manager approved the sample by } \\
\text { giving the signature in the label }\end{array}$ & $\begin{array}{l}\text { The manager approved the sample by click } \\
\text { approved in the system for the sample that } \\
\text { wants to be approved }\end{array}$ \\
\hline & & $\begin{array}{c}\text { After the manager approved the sample, } \\
\text { initiator and DC will receive the notification } \\
\text { from the email that the sample has been } \\
\text { approved }\end{array}$ \\
\hline
\end{tabular}




\begin{tabular}{|c|c|c|}
\hline \multirow{2}{*}{ Number } & \multicolumn{2}{|c|}{ Flow Business Process Comparison } \\
\hline & Current & Proposed \\
\hline \multirow[t]{2}{*}{3} & $\begin{array}{l}\text { The initiator sends the approved sample } \\
\text { to the DC }\end{array}$ & $\begin{array}{c}\text { The initiator sends the approved sample to the } \\
\text { DC and gets the label of approved sample data } \\
\text { that be printed by DC and attach it to the } \\
\text { approved sample }\end{array}$ \\
\hline & $\begin{array}{c}\text { DC key in the data of the approved } \\
\text { sample that given by initiator manually } \\
\text { into AS400 }\end{array}$ & $\begin{array}{c}\text { The data of the approved sample can be access } \\
\text { directly from the system }\end{array}$ \\
\hline \multirow[t]{2}{*}{4} & $\begin{array}{c}\text { The receiver of the related area get the } \\
\text { approved sample from } D C \text { and give the } \\
\text { signature in the form given by } D C \text { as the } \\
\text { proof that the approved sample has been } \\
\text { received }\end{array}$ & $\begin{array}{c}\text { The receiver of the related area get the } \\
\text { approved sample from DC and confirm the proof } \\
\text { that the approved sample has been received by } \\
\text { confirming it in the system }\end{array}$ \\
\hline & $\begin{array}{l}\text { Receiver input the data or key in the } \\
\text { data of approved sample into Excel }\end{array}$ & $\begin{array}{c}\text { Receiver access the data directly from the } \\
\text { system }\end{array}$ \\
\hline
\end{tabular}

\section{Conclusion}

The manual process in making the approved sample (Write the data of the sample manually in the required label) caused a bottleneck in the progress of approved sample distribution because of the limited times and resources. Another reason is in the current system, the data of the approved sample was be inputted several times in several areas when the data is the same. The tracking of the approved sample progress is limited by directly call the area or check it in the DC area directly by themselves. It takes time and resources. The sample can become approved sample after being approved by the manager, but the manager in each department did not stay in the office all day when the sample can be approved after the initiator gives it to be checked by the manager face to face. It can make the production become late from the schedule because the approved sample was not ready. Around 100 samples need to be approved each day with only one main staff in DC and limited resources in each of the areas.

After the analysis of the current system, the root cause of the problem is that some of the progress in the system was running manually many times. This problem can be handled by making a new information system using the System Development Life Cycle (SDLC) methodology. With this methodology, the new system is made using Visual Studio, Microsoft Excel, Microsoft Outlook, and Microsoft Access as the database. The implementation of the database usage successfully reducing the times in making and distribute approved sample and it makes all the areas can tracking the approved sample progress easier. With this proposed system, the data of the approved sample only be inputted one time in the beginning by the initiator and can be used by all needed areas. With this proposed system, the initiator did not need to meet the manager face to face to get the approval, and the manager can approve the sample or give the feedback to the initiator wherever they were.

\section{References}

1. Azwir, H. H., \& Patriani, O. (2017). Perbaikan Pengelolaan Pergudangan Melalui Penerapan Sistem Informasi Pergudangan di CV. ABB. Jurnal Optimasi Sistem Industri, Vol 16 No 1, pp 1024.

2. DGilca, G., \& Marian, I. (2019). Annals of the Constantin University of Targu Jiu, Engineering Science: Databases Application Developed in the Visual Studio Programming Environment. pp. 40-45.

3. Kadir, A. (2002). Pengenalan Sistem Informasi. Yogyakarta, Penerbit Andi.

4. Kendall, K., \& Kendall, J. (2014). System Analysis and Design 9th ed.

5. Le Vie, D. J. (2000). Understanding Data Flow Diagrams.

6. Percy, O., \& Amos, D. (2016) A Yll-Powered Web Application to Assist Decision-Makes in Municipal Solid Waste Management. Applied Computer Science, Vol 12 Issue 2. pp. 33-41. 
7. Putra, E. P., Fifilia, Christian, L., \& Sudarma, H., Modelling of Data Warehouse on Food Distribution Center and Reserves in the Ministry of Agriculture. ComTech, Vol 6, Issue 3 on 3 September 2015, pp. 422-434.

8. Roger, T. E., \& Dave, J. (2015). A Database in Access for Accessing Vaccine Serious Adverse Events. Vaccine: Development and Therapy. pp.9-20.

9. Rosenblatt, H. J. (2013). System Analysis and Design.

10. Sharma, M. K. (2017). International Journal of Advanced Research in Computer Science: A Study of SDLC to Develop Well Engineered Software, Vol 8, Issue 3. pp. 520-523. 